\title{
せん断ボックス試験による高濃度サスペンションの レオロジー性質に関する実験的研究 \\ EXPERIMENTAL STUDY ON RHEOLOGICAL PROPERTIES OF DENSE SUSPENSION BY SHEAR BOX TEST
}

\author{
三島直生*1, ·谷川恭雄*2; 森 博 嗣*3, 黒川善 幸*4 \\ 寺田謙 * $^{* 5}$, 服部俊範*6 \\ Naoki MISHIMA, Yasuo TANIGAWA, Hiroshi MORI, Yoshiyuki KUROKAWA, \\ Ken-ichi TERADA and Toshinori HATTORI
}

\begin{abstract}
In this study, the shear box test was carried out by using saturated sand and fresh mortar in order to grasp the rheological properties of them. As the results, it was concluded that shear stress in dense suspension increases with increasing of shear strain, because of the disappearance of excess pore water pressure with liquefaction and the decrease of pore water pressure by dilatancy. . From the experimental results obtained by using saturated sand, the coefficient of dynamic internal friction was obtained, which is needed to express the flow behavior of saturated sand. From the experimental results obtained by using fresh mortar, it was clarified that only a part of high-fluidity mortar can be expressed by Bingham's model.
\end{abstract}

Keywords : coefficient of dynamic internal friction, dilatancy, fresh mortar, rheology, saturated sand, shear box test,

動的内部摩擦係数、ダイラタンシー、フレッシュモルタル、レオロジー、飽和砂、 せん断ボックス試験、

1.はじめに

フレッシェコシクリートのレオロジーに関する多くの研究では、

降伏値および塑性粘度の2つのBingham定数による特性の定量化が試 みられている。しかし、均質粘塑性体を仮定したBinghamモデルの 適用範囲は極めて狭く、高流動モルタルのような極めて軟らかい試 料に限られている。

通常のコンシステンシンょり硬練りの範囲のフレッシュコンク リートのレオロジー的な性質は、まだ正確には把握されていない。 粉粒体の破壊条件を表すMohr·Coulombモデルによる定量化を試み

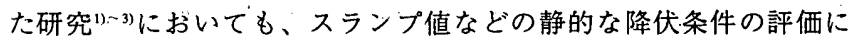
とどまっている。また、筆者らは、既にBingham定数の応力依存性 を考虑した複合モデルを提案しているが、フレッシュコンクリー トの流動挙動を十分に表現するには至っていない。

一方、地盤工学の分野においては、従来、液状化現象による被害 が数多く報告されており、近年の調査・研究によれば、地盤の液状 化に起因する側方流動により建築構造物の杭基礎に多くの被害が発 生していることが明らかとなっだっこのため、液状化に伴う流動 のメカニズムを把握するとともに、その挙動の予測が重要課題とな
っている。

砂地盤が液状化に至るまでの研究は現在までに数多く行われてお ク、そのメカニズムも把握されつつある。これに対し、液状化後の 飽和砂の力学的性質には不明な点が多く、また、ひずみが数十\%に. も及ぶせん断変形を再現できる試験方法がないなどの理由から、飽 和砂の流動現象に関する研究は極めて少なく、Newton流体 ${ }^{6}$ や Bingham流体”、限界せん断ひずみを持つ擬塑性流体名などを適用し た研究においても飽和砂の流動挙動を十分に表現するには至ってい ない。

そこで、本研究では、試料をマトリックスと固体粒子からなる2 相材料とみなして、飽和砂を試料とした大ひずみ領域までの定ひず み式単純せん断試験を行い、有効応力と内部摩擦係数をバラ゙メー夕 とするモデルを想定したうえで、飽和砂の流動性状の把握およびそ のパラメータの定量化を試みる。

さらに、フレッシュュモルタルおよびセメントペーストを試料とし た実験を行い、飽和砂の実験結果がら得られた高濃度サスペンショ ンの流動のメカニズムを適用し、フレッシュモルタルのより正確な レオロジー性質の把握および影響因子の検討を行う。

\footnotetext{
*1 名古屋大学大学院工学研究科建築学専攻 大学院生 $\cdot$ 工修

*2 名古屋大学大学院工学研究科建筑学尃攻 教授. 傅

*3 名古屋大学大学院工学研究科建築学専攻 助教授・主博

*4 名古屋大学大学院工学研究科建筑学専攻 助手. 工修

*5 鑯高組技術研究所 主席研究員・工博

*6 名古屋大学大学院工学研究科建築学専攻 大学院生
}

Graduate Student, Dept. of Architecture, Graduate School of Engineering, Nagoya Univ., M. Eng

Prof., Dept. of Architecture, Graduate School of Engineering, "Nagoya' Univ., Prof., Dept. of Architecture, Graduate School of Engineering, Nagoya Univ.,
Dr. Eng. Dr. Eng.
Assoc. Prof., Dept. of Architecture, Graduate School of Engineering, Nagoya Univ., Dr. Eng.

Research Assoc., Dept. of Architecture, Graduate School of Engineering, Nagoya Univ., M. Eng.

Senior Research Engineer, Technical Research Institute, Zenitaka Corporation, Dr. Eng.

Graduate Student, Dept. of Architecture, Graduate School of Engineering, Nagoya Univ. 


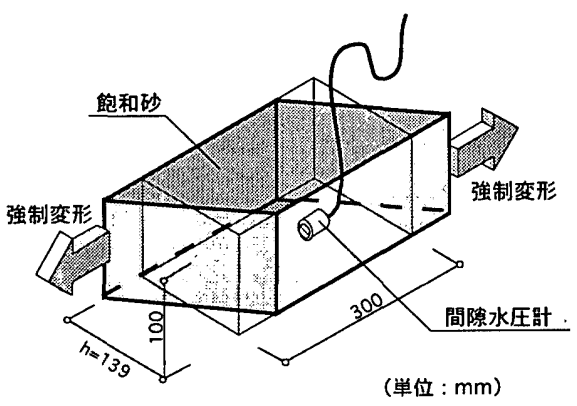

図-1 測定装置の概要

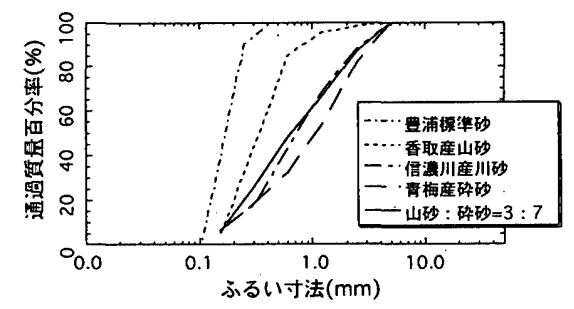

図-2＼cjkstart粒径加積曲線

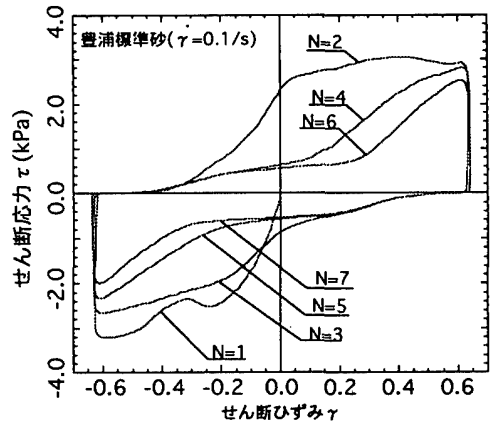

(a) 試料充填直後

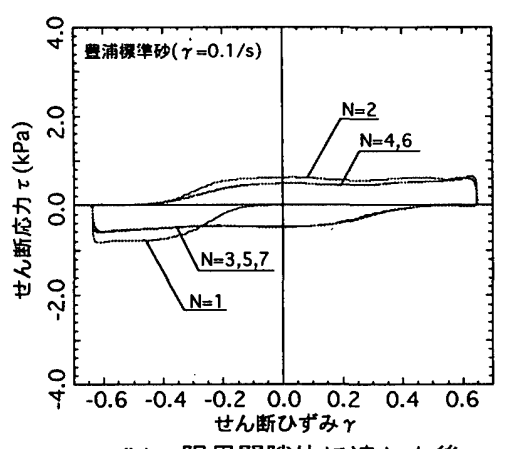

(b) 限界間隙比に達した後

图-3 せん断応力 $\tau$ とせん断ひずみみの関係の一例

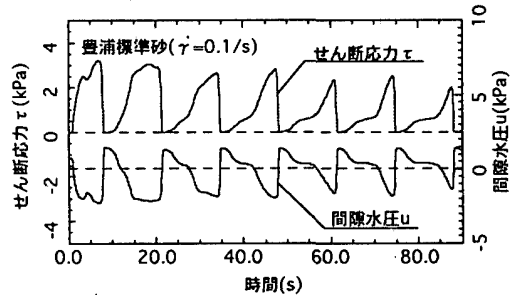

(a) 試料充填直後

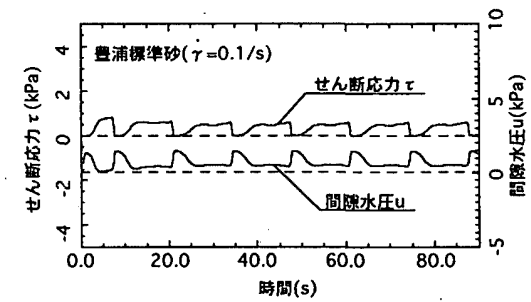

(b) 限界間隙比に達した後
表-1 砂の物理特性

\begin{tabular}{c||c|c|c|c}
\hline 種類 & $\begin{array}{c}\text { 密度 } \\
\left(\mathrm{g} / \mathrm{cm}^{3}\right)\end{array}$ & $\begin{array}{c}\text { 実皘率 } \\
(\%)\end{array}$ & $\begin{array}{c}\text { 粗粒率 } \\
\text { F.M. }\end{array}$ & $\begin{array}{c}\text { 洗い試験によ } \\
\text { る損失量 }(\%)\end{array}$ \\
\hline \hline 豊浦標準砂 & 2.64 & 62.3 & 2.09 & 0.00 \\
\hline 香取産山砂 & 2.40 & 65.3 & 1.74 & 2.24 \\
\hline 信濃川産川砂 & 2.54 & 71.4 & 2.76 & 3.05 \\
\hline 青梅産砕砂 & 2.51 & 72.5 & 3.07 & 5.12 \\
\hline \multicolumn{1}{|c|}{}
\end{tabular}

\section{2. 飽和砂を試料とした実験}

\section{1 実験装置と測定方法}

実験には図-1に示すような鉛直型せん断ボックス試験装置9) 10)を 用い、一定ひずみ速度のもとで試料に対して繰返しせん断変形を与 えた。本装置は最大で士0.64のせん断ひずみを与えることができる が、強制変形の反転に要する加・減速領域を考慮して、士0.60の範 囲の測定值を考察に用いた。せん断応力 抗力から算出し、また、試料底部に埋設した小型の間䏚水圧計によ $\eta 、$ 変形時の間隙水圧 $u$ を測定した。

せん断ひずみ速度 $\dot{\gamma}$ は $0.1,0.2,0.4,0.6,0.9 / \mathrm{s}$ の 5 水準に変化させ、 各速度ごとに3〜4往復ずつ繰返しせん断変形を与えた。測定は、試

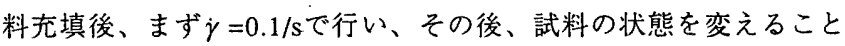
なく、上記の5水準の測定を任意の順番で行った。

試験時の境界条件は、試料上面のみが自由表面であり、この面に おける試料の体積変化および吸排水は自由とした。

\section{2 試料}

試料として用いた砂は、豊浦標準砂、香取産山砂、信濃川産川 砂、青梅産砕砂の、粒度分布の異なる4種類である。また、上記の4 種類に加えて、3節のモルタルに用いた山砂と砕砂を3:7の質量比 で混合した試料についても測定した。図-2に粒径加積曲線を、表-1 に砂の物理特性を示す。なお、試験器内では飽和砂が作成できない ため、事前に飽和させた砂を試験に用いた。
図-4 せん断応力ておよび間隙水圧uの時刻歴の一例

\section{3 実験結果とその考察}

図-3に、実験で測定されたせん断応力 $\tau$ とせん断ひずみ関係 を、図-4に、せん断応力 $\tau$ と間隙水圧 $u$ の時刻歴の一例を示す。図-3 に示すように、試料が負の方向に変形する時はせん断応力 $\tau$ も負と なるが、図-4以降では、せん断応力てはその絶対值で示す。

これらの図から明らかなように、せん断応力てと間隙水圧 $u$ の変化 は非常によく対応している。装置が最大に変形した直後、せん断変 形が反転する瞬間に飽和砂は液状化し、間隙水圧が上昇して、せん 断抵抗が消失する。その後、過㮃間隙水圧が消散するとともに、せ

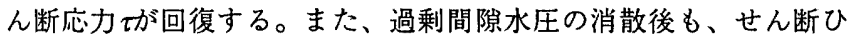
ずみ $\gamma$ の増大に伴って間隙水圧 $u$ は減少し、せん断応力 $\tau$ が増加す る。これは、正のダイラタンシーによって間隙水圧 $u$ の低下が生じ るためと考えられる。過鄱間隙水圧は、最大でも静置時に働く有効 応力分しか上昇しないが、正のダイラタンシーによる間隙水圧 $u$ の 低下は、間隙の体積の膨張による減圧であるため、下限值は決まら ず、試料の充填状態や透水性、せん断ひずみ速度、排水などの条件 によっては非常に小さい值を取る可能性もある。この時、間隙水圧 uの低下した分だけ有効応力 $p$ は増大し、せん断抵抗が増すと考えら れる。

(a) 繰返しせん断回数 $\mathrm{N}$

図-3および4の (a) は、試料充填直後に $\dot{\gamma}=0.1 / \mathrm{s}$ で測定された結果 である。図-3に示したように、繰返しせん断回数Nが増加するにし たがってループは小さくなり、ある範囲に漸近していく。これは、 流動状態において試料が収束する間隙比である限界間隙比 $e_{c r}$ が、初 期の充填状態よりも緩く、せん断変形の繰返しにより間腺比が增大 していくためと考えられる。図-3および4の (b)に示すように、試料 が限界間隙比 $e_{c k}$ 達した後の測定では、充填状態が安定していない $\mathrm{N}=1$ おび2を除けば、その水準ごとに一定の軌跡が観測された。 

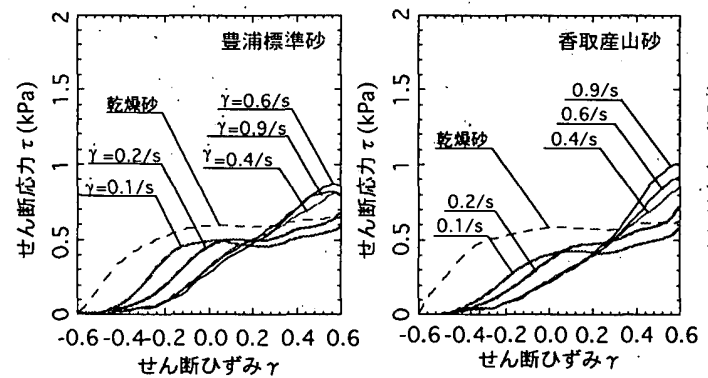

(a)
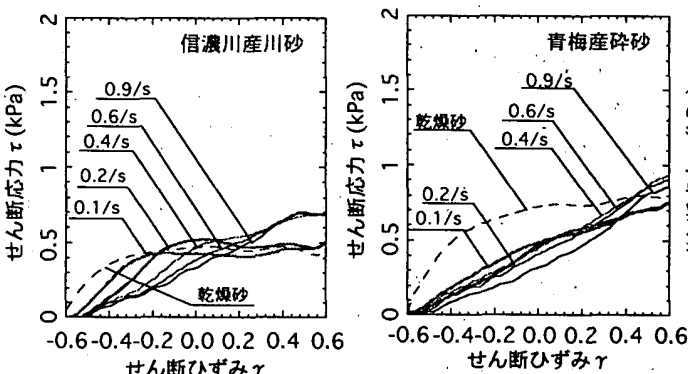

せん断ひずみて

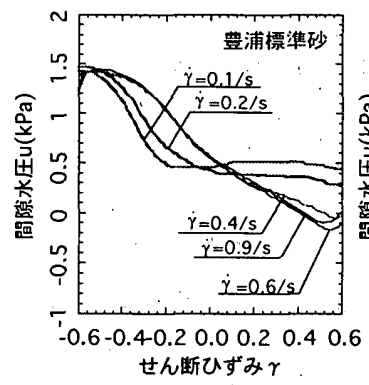

せん断ひずみ
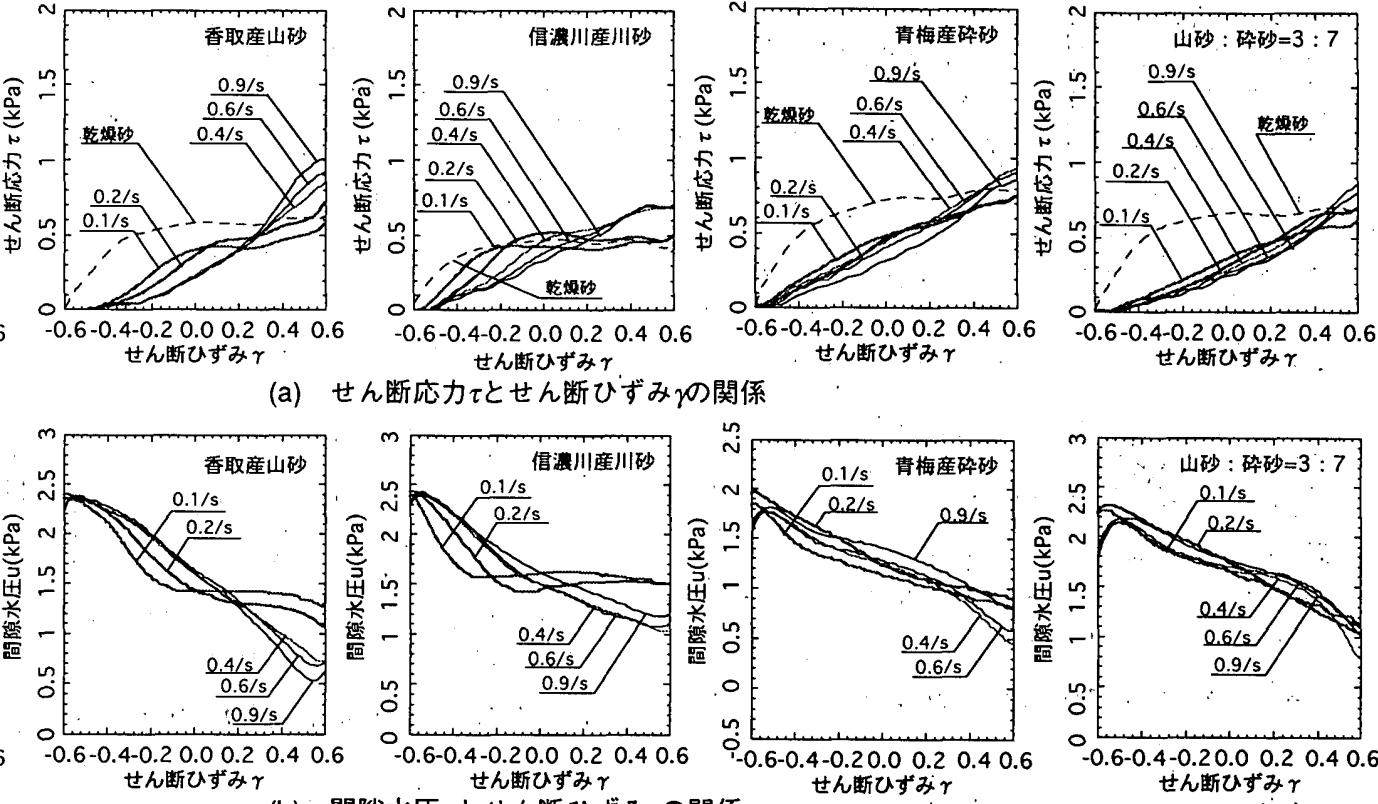

(b) 間隙水圧uとせん断ひずみみの関係

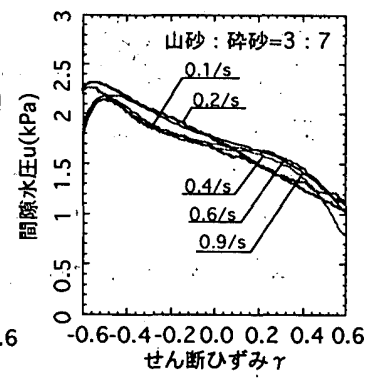

図-5 せん断ひずみの影響

(b) せん断ひずみ速度 $\gamma$

図-5に、各測定值とせん断ひずみ犺関係 を示す。各測定值は試料が限界間隙比 $e_{c r}$ に達 した後の測定值のみを示す。

豊浦標準砂、香取産山砂および信濃川産川 砂の結果では、せん断ひずみ速度 $\gamma$ が小さい ほど、関係曲線の変曲点が顕著に現れてい る。この変曲点は、液状化後に起こる過唾間 隙水圧の消散とその後の正のダイラタンシー

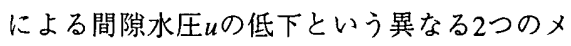
カニズムの境界を示していると考えることが できる。一方、せん断ひずみ速度 $j$ が大きい 場合、正のダイラタンシーの影響が大きく、 液状化した試料の過剩間隙水圧が消散しきら ないうちに、正のダイラタンシーが発生する ために変曲点が現れなくなるものと考えられ る。

青梅産砕砂および山砂と砕砂の混合砂で は、せん断ひずみ速度 $j$ の影響は比較的小さ い。これは、青梅産砕砂の微粒分混入量が多いことが原因と考えら れる。間隙水に微粒分が混入することにより、間隙水の粘性の増加 に起因する透水性の低下や、マトリックスと砂粒子の間の密度差が 小さくなることによる砂粒子の沈下速度の低下などの影響により、 過剩間隙水圧の消散速度が遅くなり、正のダイラタンシーの影響が 顕著となるものと考えることができる。すなわち、透水性が低い状 態では、せん断ひずみ速度 $\dot{\gamma}$ の大きい状態と類似の現象が起こって いるといえる。

図-5の (a)には、比較のために乾燥砂で同様の測定を行った結果 を破線で示したが、乾燥砂では、同一種類の砂において、せん断ひ: ずみ速度 $\gamma$ による測定值の差が全く見られなかった。このことか
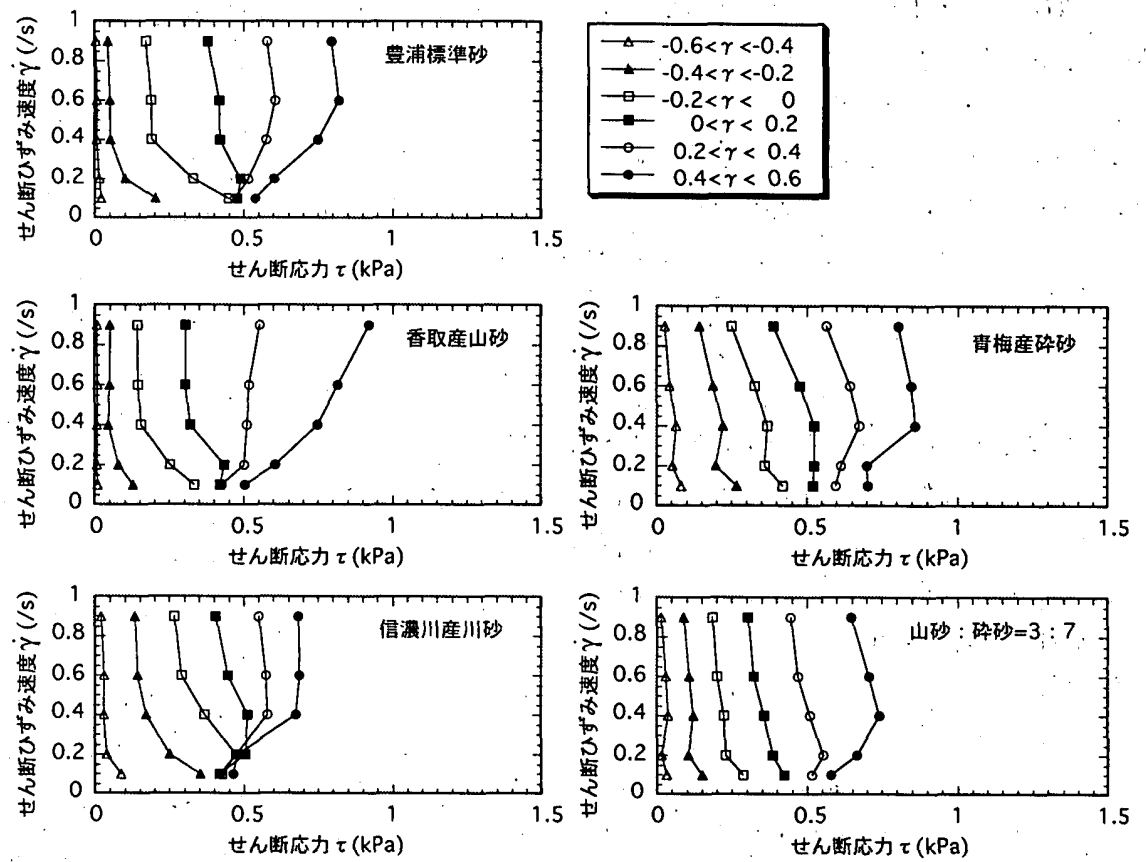

図-6 コンシステンシー曲線

ら、本実験の測定条件下においては、飽和砂のせん断ひずみ速度依 存性は、砂の透水性および間隙水の粘性によってほほ決まるものと 判断できる。

(c) コンシステンシー曲線

図-6に、飽和砂のせん断ひずみ領域ごとのコンシステンシー曲線 を示す。ただし、今回測定されたコンシステンシー曲線は、初期状 態を液状化した状態と仮定している。いずれの試料も、せん断ひず

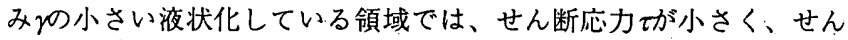
断ひずみ $\gamma を$ 増大させていくと、まず、せん断ひずみ速度の小さい 領域のせん断忘力が増大し、その後、コンシステンシー曲線が図の 右方向にシフトしながら、コンシステシシー曲線の傾きが、せん断 


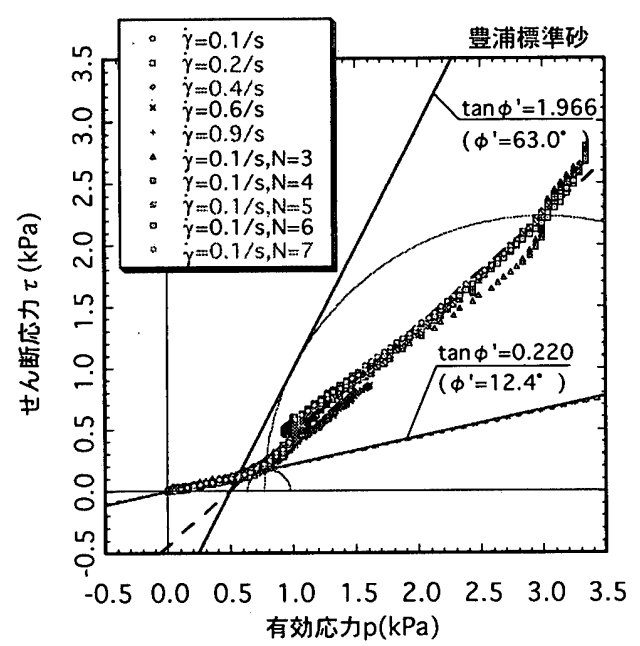

図-7 せん断応力 $\tau$ と有効応力pの関係
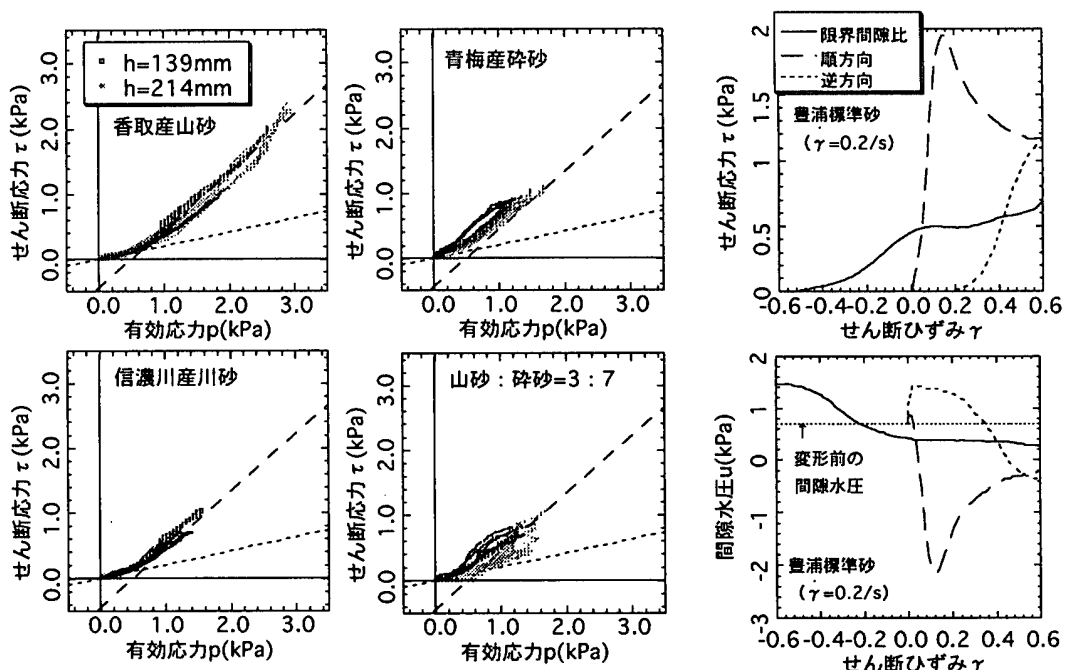

図-8＼cjkstart各砂のせん断応力 $\tau$ と有効応力pの関係

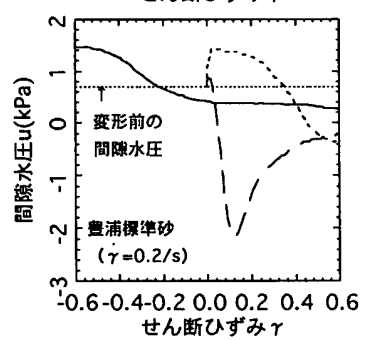

図-9 せん断変形履歴の影響
ひずみ速度 $\dot{\gamma}$ の小さい領域から順に逆転し、最終的にはBinghamモ デルに近似できるコンシステンシー曲線に近づく。

せん断ひずみの小さい段階でコンシステンシー曲線が逆勾配とな るのは、過㮃間隙水圧の消散が時間に依存した現象であるためと考 えられる。同一せん断ひずみの場合では、せん断ひずみ速度が大き いほど変形反転からの経過時間は短く、過剩間隙水圧の消散度合い が小さくなるため、せん断応力が小さくなる。その後、変形の進行 とともに、せん断ひずみ速度の小さい領域から順に過剩間隙水圧の 消散が終了するために、コンシステンシー曲線の勾配は、せん断ひ ずみ速度の小さい方から順に逆転していく。

また、コンシステンシー曲線からも、前述したような、透水性の 低い試料ほどせん断ひずみ速度の大きい状態へシフトする傾向が見 られ、これらの曲線の比較から、砂の透水性が、粒度分布および微 粒分含有量の影響で、信濃川産川砂・豊浦標準砂 ·香取産山砂・青 梅産砕砂の順で低くなっていると判断できる。

(d) 動的内部摩擦係数 $\tan \phi^{\prime}$

図-6に示すコンシステンシー曲線は、厳密に言えば近似的なもの であり、過㮃間隙水圧の消散現象が時間に依存する現象であること から、誤差が生じることが予想される。本来せん断応力 $\tau$ がせん断

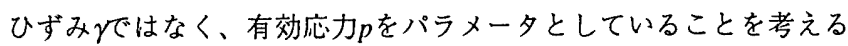
と、複雑な流動挙動を正確に表現するためには、有効応力 $p$ と内部 摩擦係数 $\tan \phi$ からせん断応力 $\tau$ を求める必要がある。そこで、全応力 が有効応力 $p$ と間隙水圧 $u$ の和であるという関係から、完全な液状化 状態でせん断応力が0のときの有効応力 $p$ をと仮定し、その状態か らの間隙水圧 $u$ の減少分を有効応力 $p$ となして算出した。

図-7に、豊浦標準砂のせん断応力 $\tau$ と有効応力 $p$ の関係を示す。図 には有効応力pの上昇域のみを示している。本実験の範囲では、2值 の関係は、せん断ひずみ速度および充填状態によらず、 $p=0.8 \mathrm{kPa}$ 付 近で交わる2本の直線で近似できる。図-5(b)に示した間隙水圧 $u$ の挙 動と比較すると、 $p<0.8 \mathrm{kPa}$ では試料は液状化状態にあり、 $p>0.8 \mathrm{kPa}$ では、正のダイラタンシーが発生していると考えられる。このこと から、 $p<0.8 \mathrm{kPa}$ の範囲では、液状化により砂粒子間の接触状態が変 化して、近似直線の勾配が減少しているものと考えられる。
また、 $p=1.0 \mathrm{kPa}$ の付近でせん断応力で゙上方にシフトする傾向が見 られる。これは、 $\gamma$ が小さい場合にのみ現れ、試料内部では、粒子 の接触状態が、有効応力 $p$ が一定のまま、液状化状態から通常の状 態に移行しているものと考えられる。 $\gamma$ が大きい場合にはこのよう な現象は観察されず、有効応力 $p$ の増加にしたがって徐々に状態が 移行していく。

図-7には、近似直線から求まる応力円の包絡線も併示した。この 包絡線は動的なCoulomb線であり、動的内部摩擦係数 $\tan \phi^{\prime}$ として、 $p<0.8 \mathrm{kPa}$ で0.220、p>0.8kPaで1.966の值が得られた。動摩擦が動的状 態にあることを条件とすることから、流動時の応力状態は、常にこ の包絡線に接する応力円上にある。

(e) せん断層厚さh

試料の寸法効果を検討するために、せん断層厚さhが2 $14 \mathrm{~mm}$ の試 験装置を用いた実験も行った。その結果、コンシステンシー曲線お よびせん断応力 $\tau$ と有効応力 $p$ の関係のいずれにおいても、前掲の $\mathrm{h}=139 \mathrm{~mm}$ の結果との大きな差異は見られなかった。図-8に、せん断 応力 $\tau$ と有効応力 $p$ の関係に関して、せん断層厚さhが $139 \mathrm{~mm}$ おび $214 \mathrm{~mm}$ の結果を重ねた結果を示す。

(f) 砂の種類

図-8中の破線は、豊浦標準砂で測定された2本の回帰曲線を示す が、この図から、砂の種類による違いは、微粒分の多い試料で相関 の悪いものがあった以外は、ほほ同じ直線上に重なった。これは、 本実験における有効応力 $p$ の範囲が極めて小さかったため、砂粒子 の表面性状の違いは現れず、また、限界間隙比 $e_{c r}$ に達した状態のみ を評価したために、砂粒子間の距離が遠くなり、砂粒子形状の影響 も現れなかったものと考えられる。

(g) せん断変形履歷

図-9に、せん断応力 $\tau$ およ゙間隙水圧 $u$ とせん断ひずみみの関係に及 ほす、変形開始以前のせん断変形履歴の影響の一例を示す。図は、 $\mathrm{N}=1$ の変形開始時の測定結果であり、せん断ひずみ $\gamma=0$ から変形を開 始している。変形開始以前に受けた変形の方向と同じ方向に変形さ せた場合を順方向、逆方向に変形させた場合を逆方向として結果を 示す。また、比較のために限界間隙比 $e_{c r}$ に達した後の測定結果も併 
せて示す。図から明らかなように、せん断変形履歴によってその性 状は全く異なり、順方向に変形させた場合には、せん断応力枋変 形開始とともに急激に増加するのに対し：逆方向の場合には、変形 開始と同時に液状化して、せん断応力脰消失する。この結果か ら、側方流動後の飽和砂地盤は、流動方向と逆方向の変形を受けた 場合に、容易に液状化することが予測される。

\section{4 飽和砂を試料とした実験のまとめ}

飽和砂のような高濃度サスペンションの流動挙動には、液状化に よる過剩間隙水圧だけでなく、正のダイラタンシーによる間隙水圧 の低下が大きく影響を及はしていることが実験により明らかとなっ た。また、そのコンシステンジー曲線は、せん断ひずみに依存して いる。間隙水圧の測定結果からは、飽和砂の流動挙動を予測するた めに必要となる動的内部摩擦係数を求めることができた。

\section{3.モルタルおよびセメントペーストを試料とした実験}

\section{1 実験装置と測定方法}

実験には、飽和砂の場合と同様に、せん断層厚さ $\mathrm{h}=139 \mathrm{~mm}$ の鉛 直型せん断ボックス試験装置を用いた。ただし、セメントを混入し た場合には、間隙水圧計による測定が困難であるため、間隙水圧の 測定は行っていない。

モルタルには、山砂：砕砂を $3: 7$ の比率で混合した砂を用いた。 表-2に今回の実験に用いた試料の調合およびモルタルフロー試験結 果を示す。

砂粒子の混入量の違いの影響を検証するために、容積比 $\mathrm{s} / \mathrm{m}$ を 50 , $55,57.5(\%)$ の3水準に変化させた。この時、砂の混入量の違いのみ を評価するために、マトリックスとなるセメントペーストの調合は 一定とした。また、セメントペーストの性質の違いの影響を見るた めに、 $\mathrm{s} / \mathrm{m}=50 \%$ の時の0回落下時のモルタルフロー值 Fl.oを $100 \mathrm{~mm}$ 程 度および $200 \mathrm{~mm}$ 以上2 2 水準に変化させ、また、 $\mathrm{s} / \mathrm{m}=57.5 \%$ の時の0 回落下時のモルタルフロー值 $\mathrm{Fl} .0$ を $200 \mathrm{~mm}$ 程度となるように流動化
表-2 モルタルおよびペーストの調合および モルタルフロー試験結果

\begin{tabular}{|c|c|c|c|c|c|c|c|c|}
\hline No. & $\begin{array}{r}\text { W/C } \\
(\%)\end{array}$ & $\begin{array}{l}\mathrm{s} / \mathrm{m} \\
(\%)\end{array}$ & $\begin{array}{c}\mathrm{W} \\
\left(\mathrm{kg} / \mathrm{m}^{3}\right)\end{array}$ & $\begin{array}{c}\mathrm{C} \\
\left(\mathrm{kg} / \mathrm{m}^{3}\right)\end{array}$ & $\begin{array}{c}\mathrm{S} \\
\left(\mathrm{kg} / \mathrm{m}^{3}\right)\end{array}$ & $\begin{array}{c}\mathrm{HAE} / \mathrm{C} \\
(\%)\end{array}$ & $\begin{array}{l}\mathrm{Fl}_{. o} \\
(\mathrm{~mm})\end{array}$ & $\begin{array}{l}\text { Fl. } \\
(\mathrm{mm})\end{array}$ \\
\hline 1 & \multirow{5}{*}{30} & 50.0 & 243 & 811 & 1,300 & \multirow{3}{*}{2.2} & 273 & - \\
\hline 2 & & 55.0 & 219 & 730 & 1,430 & & 205 & 243 \\
\hline 3 & & 57.5 & 207 & 689 & 1,495 & & 137 & 190 \\
\hline 4 & & 50.0 & 243 & 811 & 1,300 & 1.2 & 124 & 201 \\
\hline 5 & & 57.5 & 207. & 689 & 1,495 & 3.2 & 201 & $240^{\circ}$ \\
\hline 6 & \multirow{5}{*}{40} & 50.0 & 279 & 698 & 1,300 & \multirow{3}{*}{0.8} & 202 & 258 \\
\hline 7 & & 55.0 & 251 & 628 & 1,430 & & 103 & 204 \\
\hline 8 & & 57.5 & 237 & 593 & 1,495 & & 91 & 170 \\
\hline 9 & & 50.0 & 279 & 698 & 1,300 & 0.2 & 95 & 202 \\
\hline 10 & & 57.5 & 237 & 593 & 1,495 & 1.5 & 229 & 272 \\
\hline $\mathrm{p}-1$ & 30 & \multirow{3}{*}{0.0} & 487 & 1,622 & \multirow{3}{*}{0} & \multirow{2}{*}{0.2} & - & - \\
\hline $\mathrm{p}-2$ & 40 & & 558 & 1,396 & & & - & - \\
\hline$p-3$ & 29 & & 478 & 1,649 & & 0.0 & - & - \\
\hline
\end{tabular}

[Notes] W/C: Water-cement ratio, s/m: Volumetric sand-mortar ratio, W: Water, C: Cement, S: Fine aggregate, HAE: High-range water reducing $\mathrm{AE}$ agent, Fl.o: Mortar flow value befor drop, Fl.: Mortar flow value after 15 times drop.

させた試料の試験も行った。水セメント比W/Cは全ての試料で $30 \%$ および40\%の2水準とした。0回落下時のモルタルフロー值Fl.oは、高. 性能AE減水剂添加量HAE/Cで調節した。

マトリックスとなるセメントペーストのみの試験も行ったが、高 性能AE減水剂の添加率HAE/Cをモルタルの場合と同一にすると、 セメント粒子の分離が著しくなるため、添加量を減らした試料を用 いた。また、高性能AE減水剂を添加しない、硬練りのセメント ペーストの試験も行った。

\section{2 実験結果とその考察}

図-10にせん断ボックス試験で測定されたモルタルのせん断応力 $\tau$ とせん断ひずみ関係を示す。図中に示す曲線は、それぞれせん
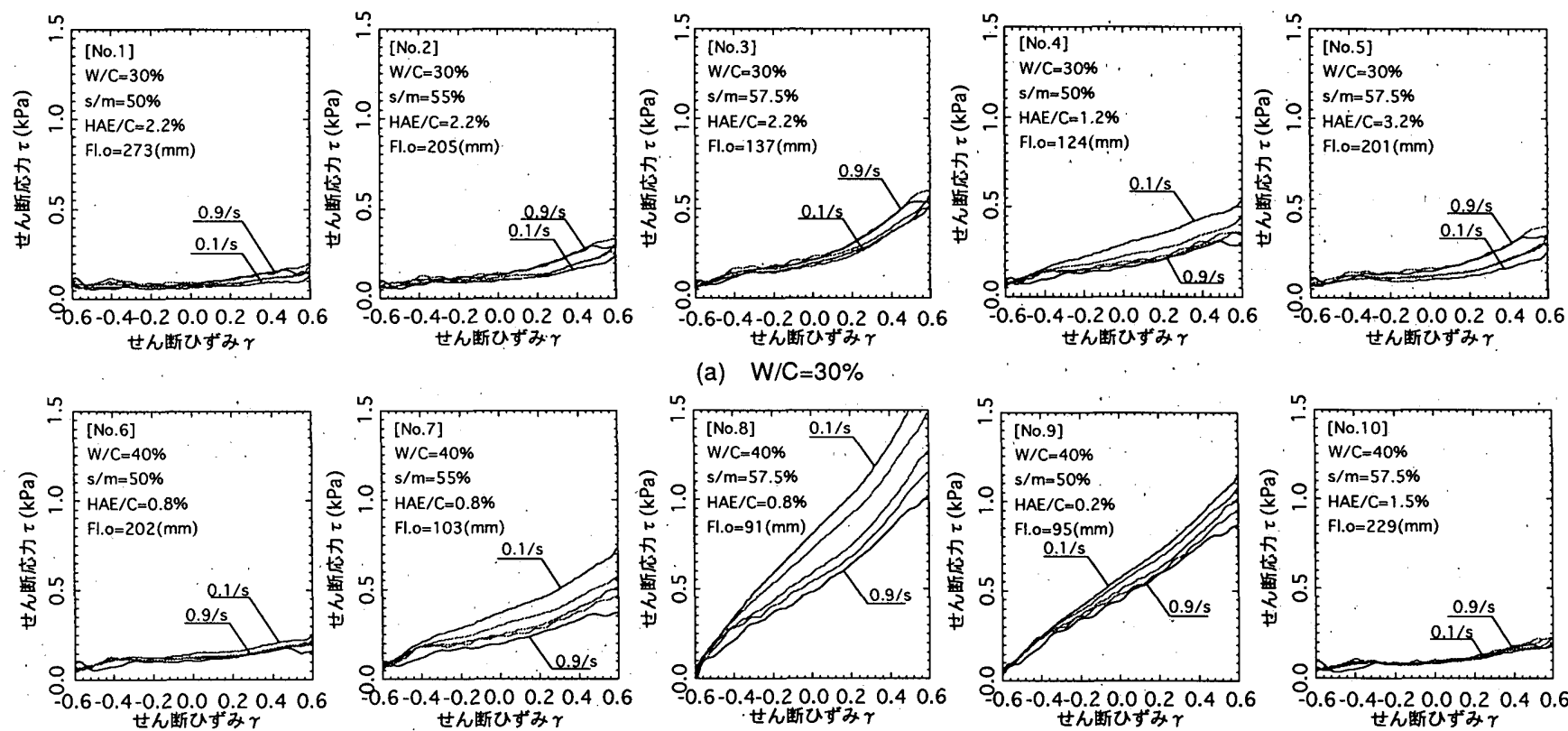

(a) $\mathrm{W} / \mathrm{C}=30 \%$

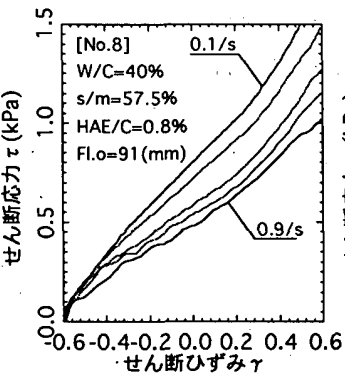

(b) $\mathrm{W} / \mathrm{C}=40 \%$

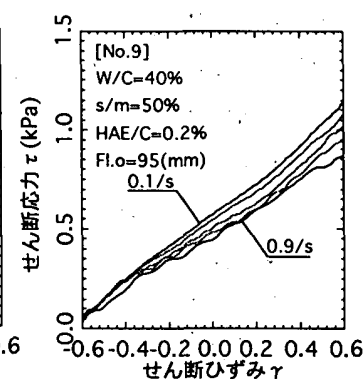

せん断ひずみ $\gamma$

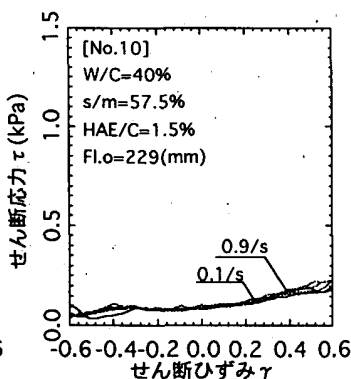

せん断ひずみ

図-10 せん断応力てとせん断ひずみみの関係 
断ひずみ速度を $\dot{\gamma}=0.1,0.2,0.4,0.6,0.9 / \mathrm{s}$ で変形 させた場合の結果である。図からわかるよう に、モルタルのせん断ひずみ依存性は調合に よって全く異なる。

せん断応力てとせん断ひずみ関係曲線の 勾配は、ダイラタンシーに起因するものであ ク、この勾配が大きいほどサスペンション特 有の性質が顕著に現れていることを示す。逆 に、完全なBingham流体ではこのような勾配は 現れず、せん断応力 $\tau$ は一定となるはずであ る。

\section{(a) 細骨材容積率 $\mathrm{s} / \mathrm{m}$}

細骨材容積率 $\mathrm{s} / \mathrm{m}$ を変化させた試料No.1〜 No.3およびNo.6〜No.8を比較すると、 $\mathrm{s} / \mathrm{m}$ の増 加に伴ってせん断応力 てとせん断ひずみ城 係曲線の勾配が大きくなっている。これは、 マトリックスの性質が一定ならば、固体粒子 の混入量が多いほど、せん断応力 $\tau$ のせん断ひ ずみ依存性が顕著に現れることを示してい る。

なお、W/C $=40 \% の$ 試料の方がW/C $=30 \% の$ 試料に比べて勾配が急であるが、これは0回落 下時のモルタルフロー值Fl.0の違いによるもの と考えられる。

(b) セメントペーストの流動性

試料No.1,6から、混和荗添加量HAE/Cを減 らして、セメントペーストの流動性を下げた 試料No.4, 9では、曲線の勾配が大きくなり、 せん断ひずみ依存性が顕著に現れている。

一方、試料No.3,8加ら、混和剂添加量HAE/ Cを増やして、セメントペーストの流動性を上 げた試料No.5, 10では、細骨材容積率 $\mathrm{s} / \mathrm{m}$ が大 きいにもかかわらず、曲線の勾配は小さい。 このことから、高性能AE減水剤を多量に添加 し、セメントペーストの流動性を上げれば、曲線の勾配は小さくな ク、Bingham流体に近い挙動を示すことがわかる。

(c) コンシステンシー曲線

図-11に、せん断ひずみ領域ごとのコンシステンシー曲線を示 す。フレッシュモルタルの場合には、飽和砂で見られたような、せ

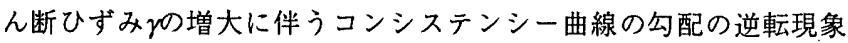
は観察されなかったが、せん断ひずみ増大とともにせん断応力 $\tau$ が増大し、コンシステンシー曲線が右方向にシフトしていく傾向 は、程度の差はあるものの、すべての試料で確認された。

$\mathrm{W} / \mathrm{C}=30 \%$ の試料では、試料No.4を除いて、右上がりのコンシス テンシー曲線が測定されているのに対し、W/C=40\%の試料では、試 料No.10を除いて、右下がりのコンシステンシー曲線が測定されて いる。

この結果から、コンシステンシー曲線の傾きの正・負は、単純に セメントペーストの軟らかさによって決まるのではなく、混和剤添 加量HAE/Cが直接影響していることがわかる。すなわち、高性能
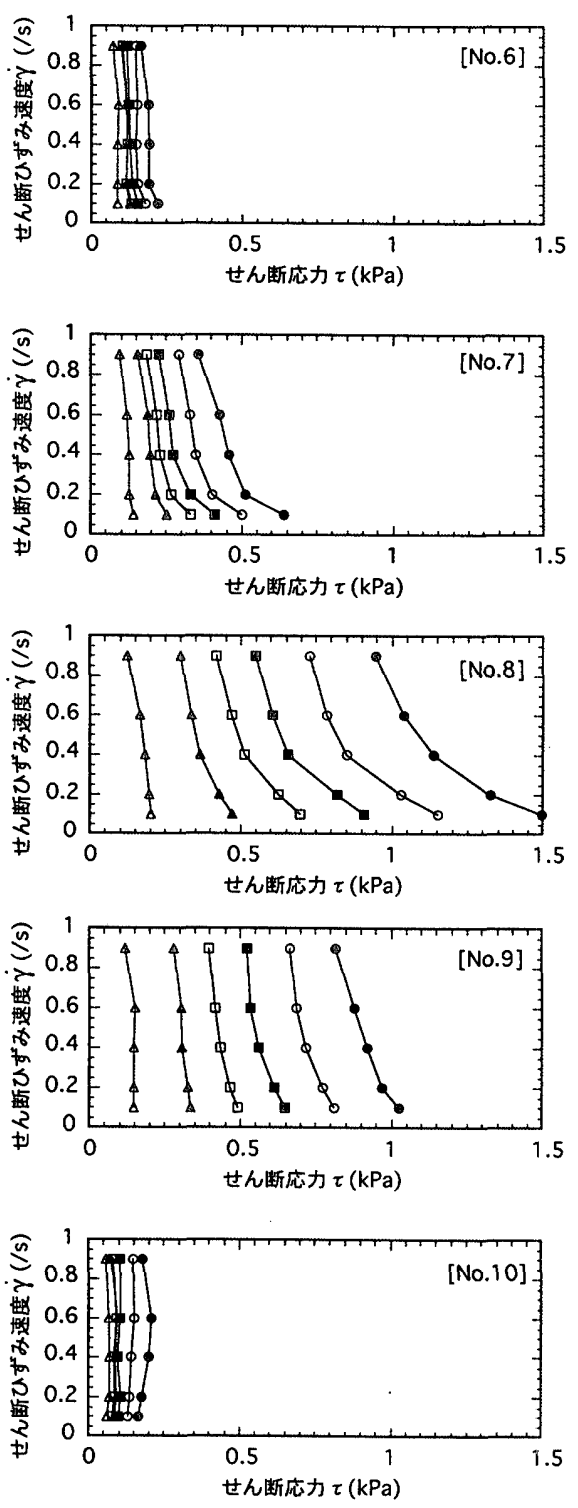

(b) $\mathrm{W} / \mathrm{C}=40 \%$

図-11 コンシステンシー曲線

$\mathrm{AE}$ 減水剂は、セメント粒子を分散させてセメントペーストを流動 化させる作用があるが、その他にも、固体粒子間の摩擦を低減する 潤滑作用を持つ可能性が考えられる。この場合、サスペンションの

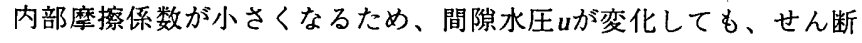
応力 てはほとんど変化しないことが予想される。仮に、動的な内部

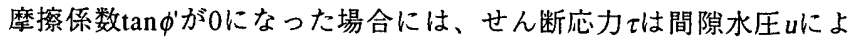
らず、セメントペーストの性質とその変形領域のみによって決まる ため、Bingham流体と仮定することができる。W/C=30\%のモルタル では、 $\mathrm{HAE} / \mathrm{C}=2.2 \sim 3.2 \%$ と混和侴添加量が大きいためにコンシステ ンシー曲線が右上がりになり、また、W/C=40\%の中で唯一右上がり となる試料No.10についても、 $\mathrm{HAE} / \mathrm{C}=1.5 \%$ と他の試料に比べて大き いことからも、これが説明できる。

一方、混和剤添加量が小さい試料のコンシステンシー曲線が逆勾 配となるのは、前述の飽和砂の場合と同様で、過剩間隙水圧の影響 と考えられる。ただし、モルタルの場合にはセメントの混入により マトリックスの粘性が高くなり、過剩間隙水圧の消散速度が遅いた 
めに、全ひずみ領域において過㮃間隙水圧の

影響が現れたものと考えられる。

(d) セメントペーストの測定結果

図-12に、七メシトペーストのせん断応力 $\tau$ とせん断ひずみ関係曲線を示す。試料No.p $-1,2$ では、せん断ひずみ 㐫力ての増加は測定されず、ほほBingham流体 とみなすことができる。一方、混和片を添加 していない試料No.p-3では、同関係曲線に明

らかに勾配が現れ、調合によってはセメント
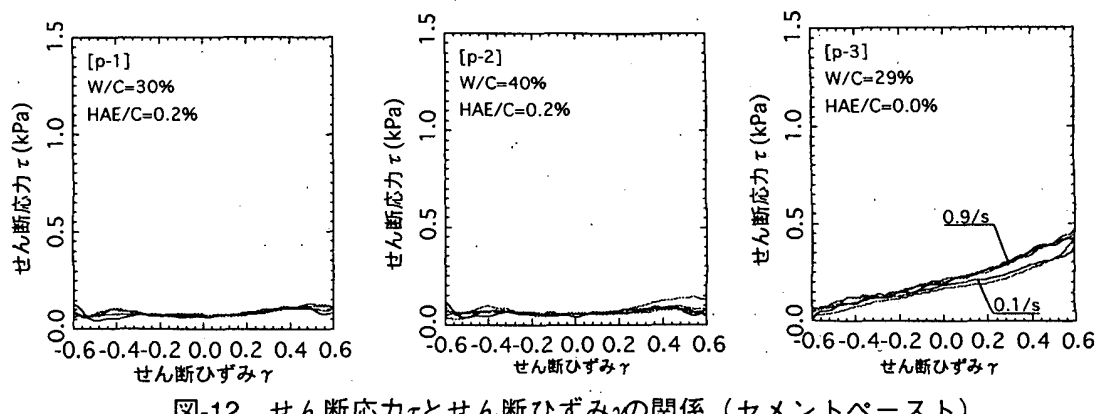

.図-12 せん断応力 $\tau$ せん断ひずみみの関係（セメントペースト）

ペーストでも、ダイラタンシーに起因するせん断応力のせん断ひず み依存性をしめすことが明らかとなった。

3.3 モルタルおよびセメントペーストを試料とした実験のまとめ 飽和砂と同様に、フレッシュモルタルおよびペーストのせん断応 力はダイラタンシーによる間隙水圧の低下に大きく影響を受けてお り、そのコンシステンシー曲線は、せん断ひずみに依存しているこ とが明らかとなった。また、高性能AE減水剤はセメントペースト の流動性だけでなく、骨材粒子間の動的内部摩擦係数に大きく影響 を及ほしており、高性能AE減水剂の添加量が多く、かつ、流動性 の良いもののみがBingham流体としてモデル化できることがわかっ た。

\section{4. おわりに}

本研究では、高濃度サスペンションのレオロジー的な性質を把握 するために、飽和砂、フレッシュモルタルおよびペーストを試料と したせん断ボックス試験を行った。その結果、液状化後の高濃度サ スペンションの流動挙動は、せん断ひずみの進行とともに液体的な 性質から固体的な性質へと変化することが明らかとなった。今回測 定されたような、せん断ひずみに依存したコンシステンシー曲線 は、他の物質では観察されず、飽和砂やフレッシュモルタルなどの 高濃度サスペンションに特有なものである。また、固体粒子とマト リックスの間の密度差が、その性状をさらに複雑なものとしてい る。

本実験で得られた飽和砂の実験結果は、限界間隙比に達した後 の、自由排水条件下における、完全な液状化の後のレオロジー性質 であり、充填状態や排水条件、液状化の度合いなどを変化させた場 合の流動挙動に関しては、今後の研究課題といえる。

フレッシュモルタルに関しては、マトリックスのセメントペース 卜が降伏值を持つことなどの理由から、現在のところ、せん断変形 時の間隙水圧を正確に測定する方法がなく、その試験手法の検討が 重要課題である。また、高性能AE減水剂の動的内部摩擦係数に及 ほすす影響については、まだ十分に検証されていない。
本研究で得られたせん断ひずみ依存型のレオロジーモデルを用い ることにより、型枠内流動時の鉄筋間通過性や閉塞; 振動前後の性 状変化などをより正確に評価することができると考えられ、今後研 究を進めていく予定である。

フレッシュモルタルの流動性に影羱を及ほす細骨材の材料性質の 定量化手法に関しては、粒度分布や骨材の個々の形状からの把握は 困難であり、本実験で测定した飽和砂のコンシステンシー曲線など によるレオロジー的な把握手法が有效であると考えられる。

\section{謝辞}

本研究に際して、鳴滝康宏君、名口芳和君（いずれも名古屋大学 大学院生）の協力を得た。本研究費の一部は、平成 $10 \cdot 11$ 年度文部 省科学研究費補助金・基盤研究 (B) ならびに1999年度セメント協会 研究奖励金によった。付記して謝意を表する。

\section{引用文献}

1) 村田二郎：フレッシュコンクリートの流動と変形, 土木学会第 31回年次学術講演会講演概要集, pp.272-273, 1976.

2）下山善秀：静的外力による硬練りコンクリートの変形に関する 研究, 土木学会論文集, No.390/V-8, pp.141-149, 1988.2

3）越川茂雄：フレッシュコンクリートの間隙水圧挙動に関する考 察, 土木学会第 41 回年次学術講演会講演概要集, pp.465-466, 1986.11

4）森博嗣・田中政史・谷川恭雄：フレッシュコンクリートのせん 断変形性質に関する実験的研究, 日本建築学会構造系論文集, No.421, pp.1-10, 1991.3

5）時松孝次：地盤の液状化・側方流動による被害事例および設計 への展開,地盤の液状化および流動講習会講演資料, 地盤工学会, 1998.

6) 中村孝明・佐藤博・土居賢彦：BEM・FEM結合モデルによる液 状化側方流動解析, 境界要素法論文集, No.10, pp.53-58, 1993.

7）渦岡良介・八嶋厚・川上哲太郎：Bingham モデルを用いた液状 化地盤の側方流動解析, 第32回地盤工学研究発表会（熊本）， pp.893-894, 1997.7

8）濱田政則・若松加寿江：液状化による地盤の水平変位の研究, 土木学会論文集, No.596/III-43,pp.189-208, 1998.6

9) 寺田謙一・谷川恭雄・森博嗣・黑川善幸·三島直生・若林信太 郎：せん断ボックス試験に基づくモデル材料を用いたフレッシ ユコンクリートのレオロジー性質に関する研究, 日本建築学会 構造系論文集, No.511, pp.17-24, 1998.9

10）寺田謙一・谷川恭雄・森博嗣・黑川善幸 . 三島直生：フレッシ ュコンクリートのレオロジー性質に及ほすせん断層厚さおよび 粗骨材要因の影響に関する研究, 日本建築学会構造系論文集, No.513, pp.15-22, 1998.11 